\title{
Little Metalmark, Calephelis virginiensis (Guérin-Ménéville) (Insecta: Lepidoptera: Riodinidae) ${ }^{1}$
}

Donald W. Hall, Marc Minno and Jerry F. Butler²

\section{Introduction}

The little metalmark, Calephelis virginiensis (Guérin- Ménéville), is one of three allopatric metalmarks found in the eastern United States. Although the little metalmark is one of our tiniest butterflies, it is one of our most beautiful. It is the only metalmark found in the southeastern coastal plain.

\section{Distribution}

Southeastern coastal plain from southeastern Virginia to eastern Texas in uplands and marginal wetlands, sandhills, flatwoods, pine savannas, prairies, and on roadsides.

\section{Description}

Adults: The wings vary in color from rusty orange to orange-brown and have metallic silver lines on the wings - the characteristic from which the family gets the common name "metalmarks."

Eggs: The flattened eggs are reddish-brown with white sculpturing.

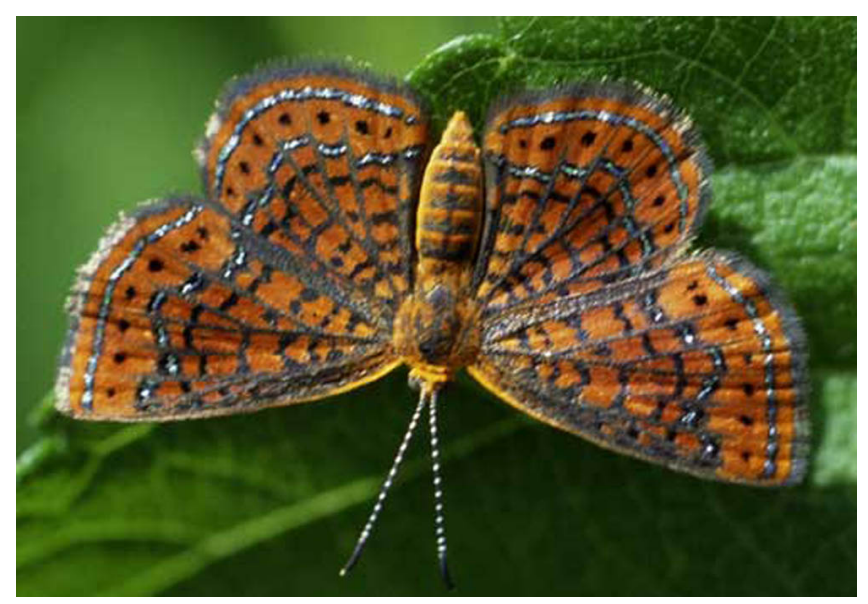

Figure 1. Adult little metalmark, Calephelis virginiensis (Guérin- Ménéville). Credits: J.F. Butler, University of Florida

Larvae: Caterpillars are light-green, stippled with many tiny white dots. There are dorsal and lateral rows of long white setae on each side and a rust-brown sub-dorsal spot on each side on abdominal segments two through seven.

Pupae: The pupae are green with dorsal and lateral rows of black spots. The pupa is covered with setae from the last instar larva- possibly for protection from predators or parasitoids.

1. This document is EENY-407 (IN734), one of a series of Featured Creatures from the Entomology and Nematology Department, Florida Cooperative Extension Service, Institute of Food and Agricultural Sciences, University of Florida. Published: May 2007. This document is also available on Featured Creatures Website at http://creatures.ifas.ufl.edu. Please visit the EDIS Website at http://edis.ifas.ufl.edu.

2. Donald W. Hall and Jerry F. Butler, Department of Entomology and Nematology, University of Florida, Gainesville, FL and Marc Minno, St. John's River Water Management District.

The Institute of Food and Agricultural Sciences (IFAS) is an Equal Opportunity Institution authorized to provide research, educational information and other services only to individuals and institutions that function with non-discrimination with respect to race, creed, color, religion, age, disability, sex, sexual orientation, marital status, national origin, political opinions or affiliations. U.S. Department of Agriculture, Cooperative Extension Service, University of Florida, IFAS, Florida A. \& M. University Cooperative Extension Program, and Boards of County Commissioners Cooperating. Larry Arrington, Dean 


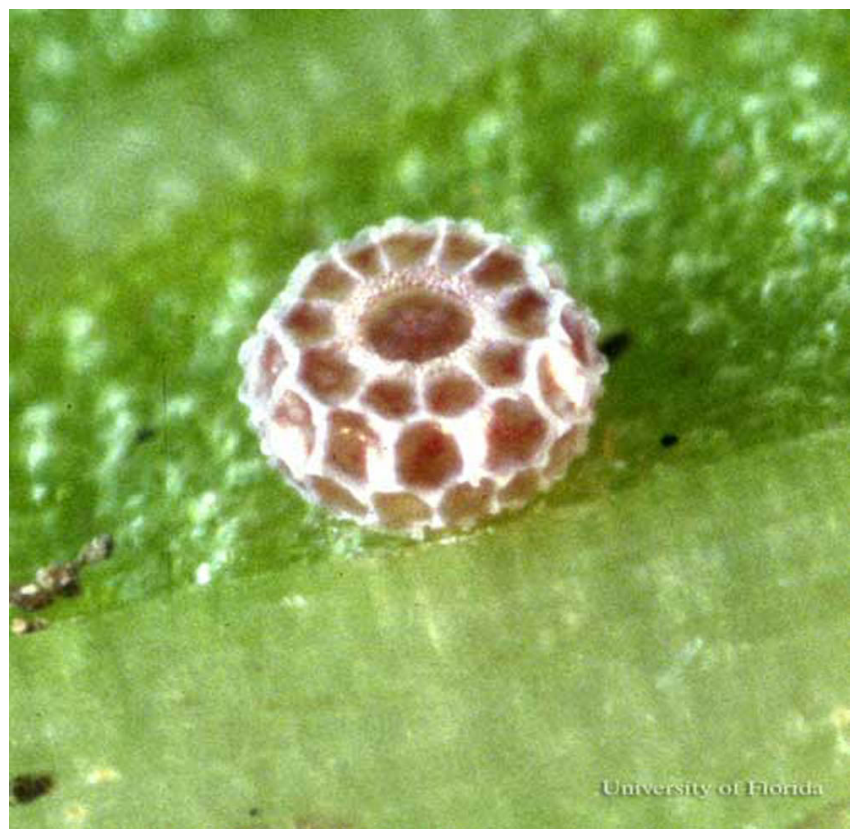

Figure 2. Egg of the little metalmark, Calephelis virginiensis (Guérin- Ménéville). Credits: J.F. Butler, University of Florida

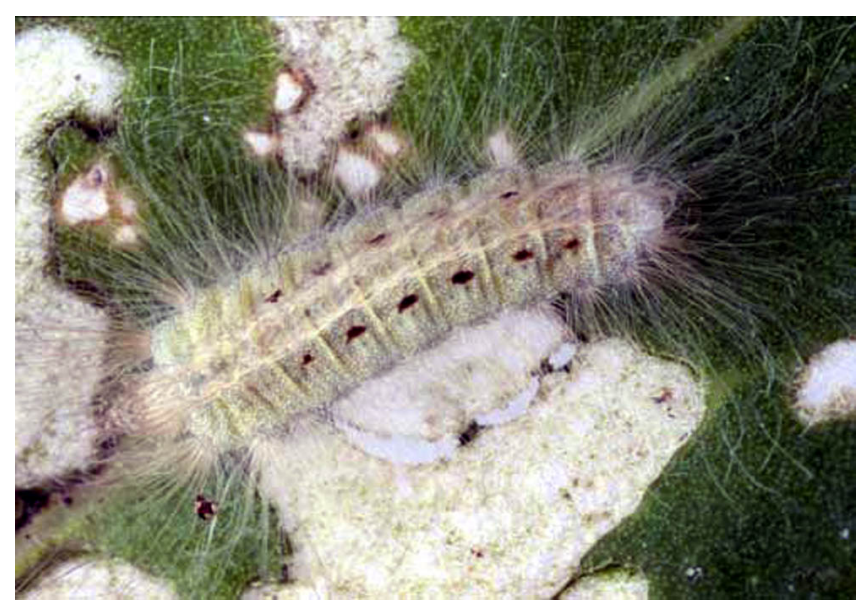

Figure 3. Larva of the little metalmark, Calephelis virginiensis (Guérin-Ménéville), dorsal view. Credits: Marc Minno, St. John's River Water Management District

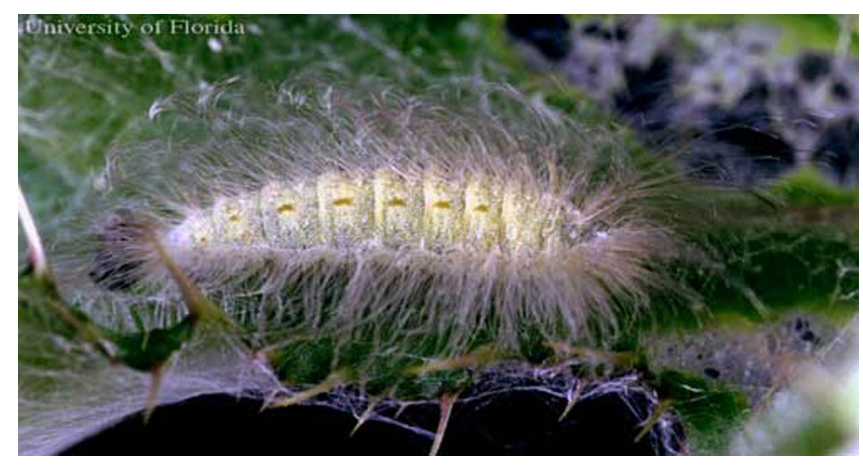

Figure 4. Larva of the little metalmark, Calephelis virginiensis (Guérin-Ménéville), dorso-lateral view. Credits: J.F. Butler, University of Florida

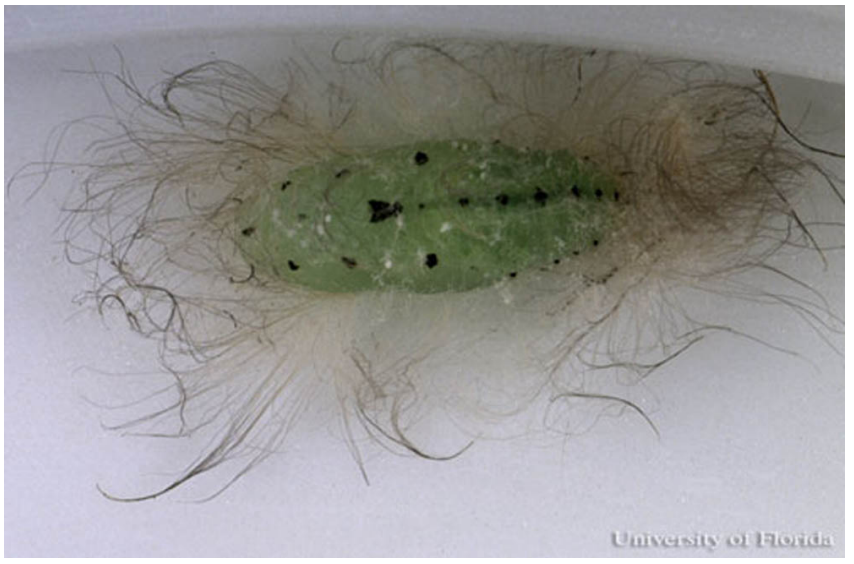

Figure 5. Pupa of the little metalmark, Calephelis virginiensis (Guérin- Ménéville), on lid of rearing container. Credits: J.F. Butler, University of Florida

\section{Life Cycle and Biology}

This metalmark is common throughout Florida, except for the Keys. At least three generations are produced each year in northern parts of its range and many flights all year in Florida (Scott 1986). It is most common during late summer and fall in Florida, but caterpillars are present from March through November (Minno et al. 2005).

Little metalmarks are low-flying and are not commonly seen until they land and rest with their wings outstretched. Adults tend to orient themselves in an upside-down position when resting. Males patrol for females but their patrolling is fairly localized. Flat-flowered composites (Asteraceae) seem to be the preferred nectar sources.

Eggs are laid singly on the underside of the host leaves. Caterpillars feed mostly at night (Cech and Tudor 2005) on the undersides of the leaves, but leave the translucent upper cuticle intact. These small circular windows in the leaves are a good sign to look for when searching for the caterpillars. Partly grown caterpillars are probably the over-wintering stage (Opler and Krizek 1984).

\section{Hosts}

Little metalmark caterpillar host plants are herbs in the Aster Family (Asteraceae) including yellow thistle, Cirsium horridulum Michx., vanillaleaf, Carphephorus odoratissimus J.F.Gmel.) H.Hebert (Minno et al. 2005, Wagner 2005) and sometimes climbing hempvine, (Mikania scandens) (L.)Willd. 
(Minno et al. 2005). Caterpillars are especially cryptic on the undersides of the leaves of yellow thistle where their hairs blend in with the long white hairs of the plant.

Yellow thistle flowers vary in color and may be white, yellow, or purple.

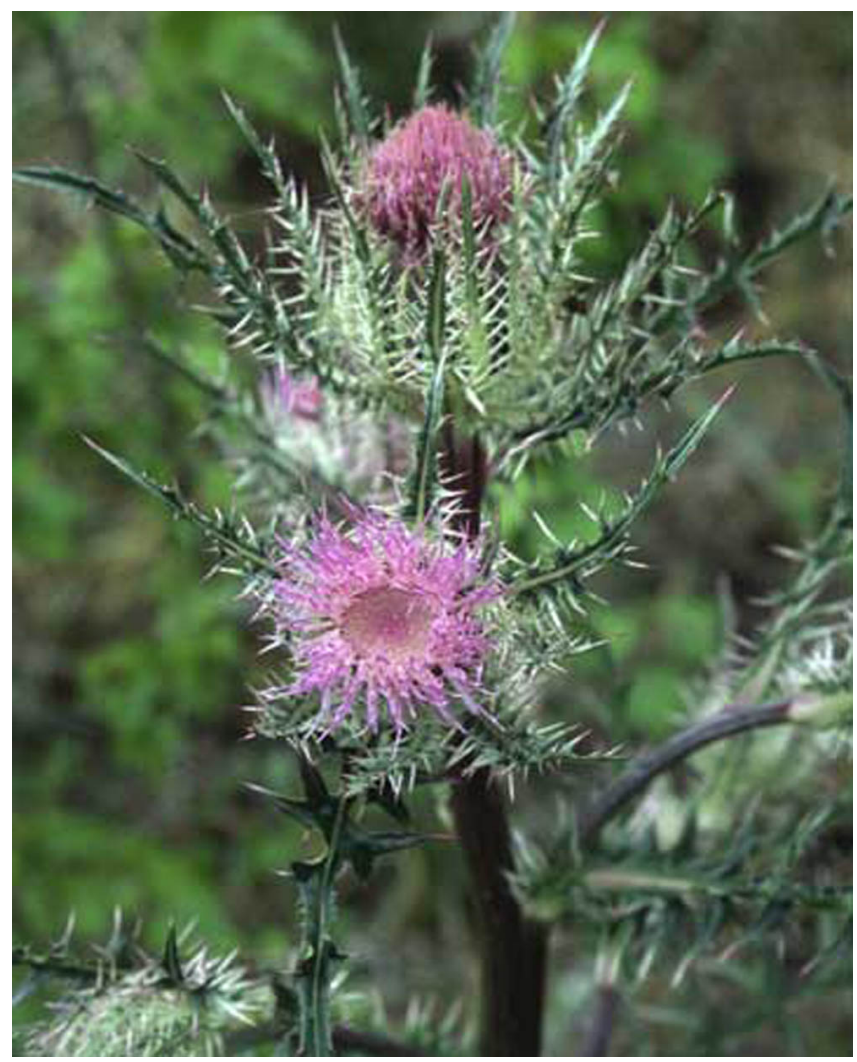

Figure 6. Purple form of yellow thistle, Cirsium horridulum Michx. Credits: Marc Minno, St. John's River Water Management District

Photographs of vanillaleaf are available at the Institute for Systematic Botany (University of South Florida) Web site: http://www.plantatlas. usf.edu/images.asp?plantID-3092\#.

\section{Selected References}

Cech R, Tudor G. 2005. Butterflies of the East Coast. Princeton University Press. Princeton, New Jersey. 345 pp.

Minno MC, Butler JF, Hall DW. 2005. Florida Butterfly Caterpillars and their Host Plants. University Press of Florida. Gainesville, Florida. 341 pp.

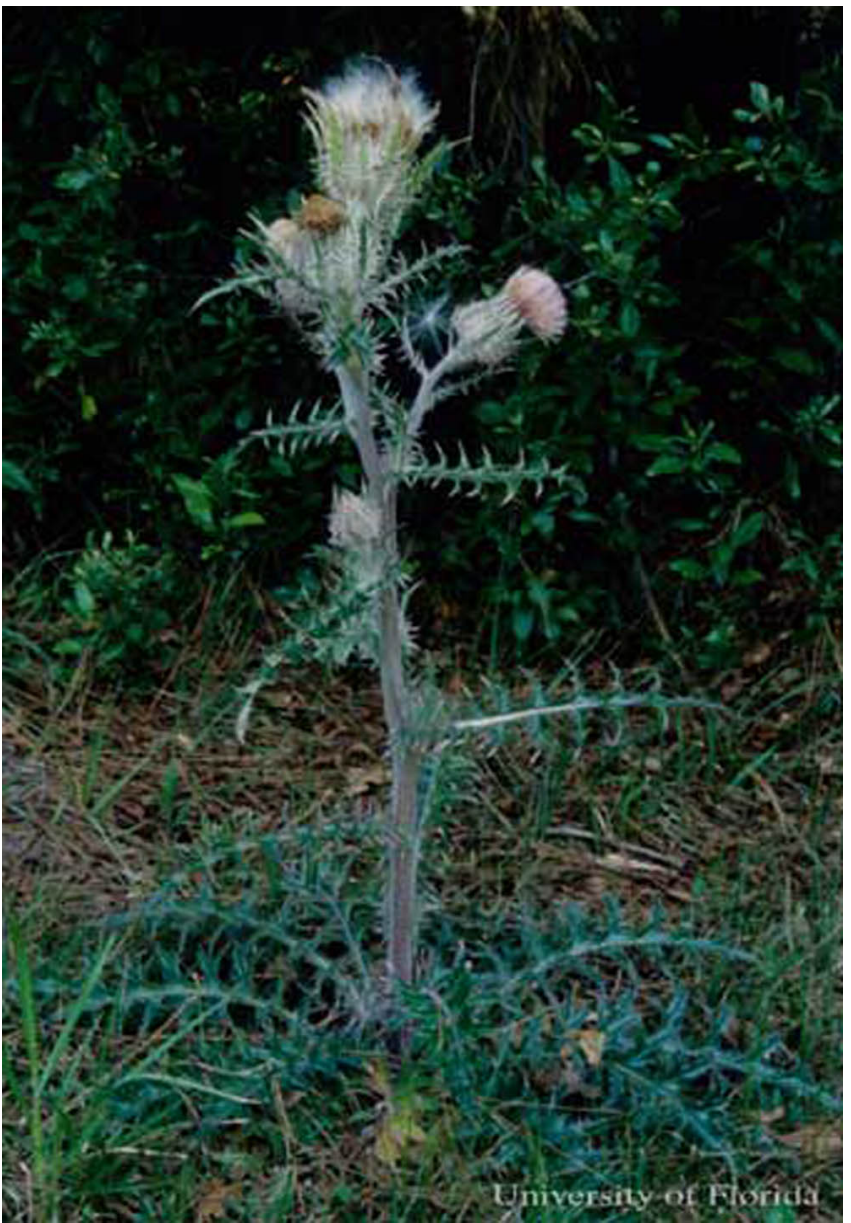

Figure 7. Purple form of yellow thistle, Cirsium horridulum Michx. Credits: Marc Minno, St. John's River Water Management District

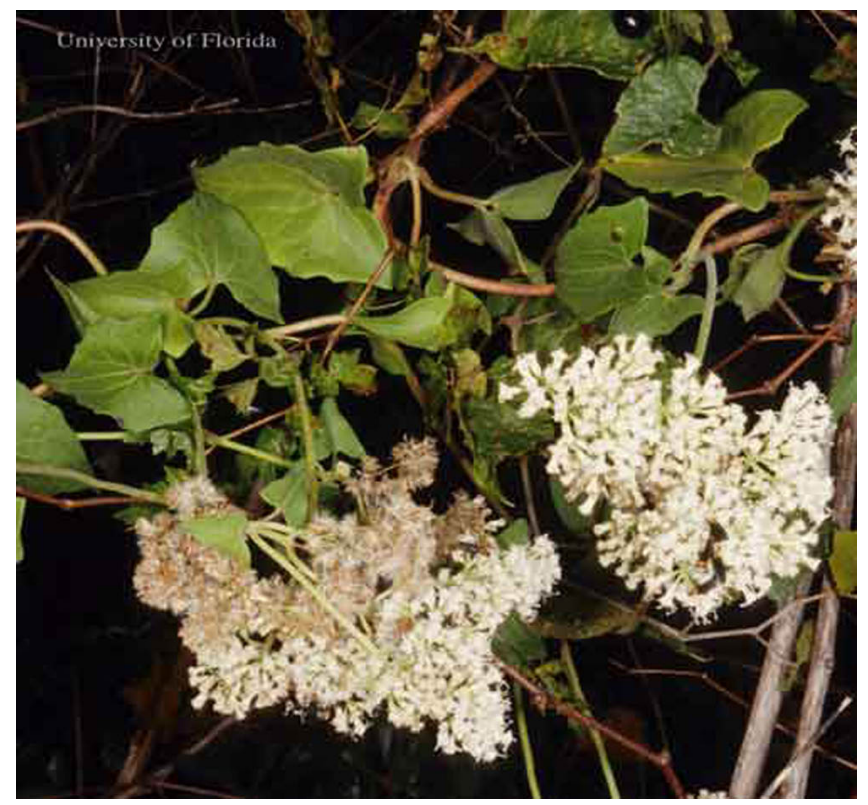

Figure 8. Climbing hempvine, Mikania scandens (L.)Willd. Credits: Donald W. Hall, University of Florida 
Opler PA, Krizek GO. 1984. Butterflies East of

the Great Plains. The Johns Hopkins University Press.

Baltimore, Maryland. 294 pp.

Scott JA. 1986. The Butterflies of North

America: A Natural History and Field Guide.

Stanford University Press. Stanford, California. 583

pp.

Wagner DL. 2005. Caterpillars of Eastern North America. Princeton University Press. Princeton, New Jersey. $512 \mathrm{pp}$. 